\title{
Quantitative expression analysis and prognostic significance of L-DOPA decarboxylase in colorectal adenocarcinoma
}

\author{
CK Kontos', IN Papadopoulos'2, EG Fragoulis' and A Scorilas*,I \\ 'Department of Biochemistry and Molecular Biology, Faculty of Biology, University of Athens, Athens GR-1570I, Greece; '² Fourth Surgery Department, \\ University General Hospital 'Attikon', I Rimini Street, Athens GR-12462, Greece
}

\begin{abstract}
BACKGROUND: L-DOPA decarboxylase (DDC) is an enzyme that catalyses, mainly, the decarboxylation of L-DOPA to dopamine and was found to be involved in many malignancies. The aim of this study was to investigate the mRNA expression levels of the DDC gene and to evaluate its clinical utility in tissues with colorectal adenocarcinoma.

METHODS: Total RNA was isolated from colorectal adenocarcinoma tissues of 95 patients. After having tested RNA quality, we prepared cDNA by reverse transcription. Highly sensitive quantitative real-time PCR method for DDC mRNA quantification was developed using the SYBR Green chemistry. GAPDH served as a housekeeping gene. Relative quantification analysis was performed using the comparative $C_{T}$ method $\left(2^{-\Delta \Delta C_{T}}\right)$.

RESULTS: DDC mRNA expression varied remarkably among colorectal tumours examined in this study. High DDC mRNA expression levels were found in well-differentiated and Dukes' stage A and B tumours. Kaplan-Meier survival curves showed that patients with DDC-positive tumours have significantly longer disease-free survival $(P=0.009)$ and overall survival $(P=0.027)$. In Cox regression analysis of the entire cohort of patients, negative DDC proved to be a significant predictor of reduced disease-free $(P=0.02 \mathrm{I})$ and overall survival $(P=0.047)$.

CONCLUSIONS: The results of the study suggest that DDC mRNA expression may be regarded as a novel potential tissue biomarker in colorectal adenocarcinoma.

British Journal of Cancer (2010) 1 02, 1384 - 1390. doi:I0.1038/sj.bjc.6605654 www.bjcancer.com

(c) 2010 Cancer Research UK
\end{abstract}

Keywords: colorectal adenocarcinoma; L-DOPA decarboxylase; DDC; real-time PCR; tumour biomarkers

Colorectal carcinoma (CRC) is the third most common malignant tumour and the fourth most common cause of cancer death in the world (Parkin et al, 2001a; Jemal et al, 2009). The prognosis of patients with CRC largely depends on the degree of penetration of the tumour through the bowel wall, the nodal status, and the presence or absence of distal metastases (Steinberg et al, 1986). These three characteristics are the key features of all clinical staging systems developed for this disease (Compton and Greene, 2004).

In spite of the fact that clinicopathological staging separates patients with CRC into groups with distinct outcomes, it provides little information about response to treatment in individual patients (Walther et al, 2009). In an attempt to refine prognostication and predict the benefit derived from systemic treatment, several protein and genetic markers have been evaluated in patients with CRC, including allelic loss of chromosome 18q (Jen et al, 1994; Martinez-Lopez et al, 1998; Ogunbiyi et al, 1998; Popat and Houlston, 2005), absence of the deleted in colorectal carcinoma (DCC) protein (Shibata et al, 1996; Reymond et al, 1998; Popat and Houlston, 2005), decreased SMAD4 mRNA

*Correspondence: Dr A Scorilas; E-mail: ascorilas@biol.uoa.gr or scorilas@netscape.net

Received I5 December 2009; revised 8 March 2010; accepted I8 March 2010 expression (Boulay et al, 2002; Alazzouzi et al, 2005), expression and/or abnormalities of cytoplasmic oncoprotein p53 (TP53) (Sun et al, 1992; Munro et al, 2005; Russo et al, 2005), protein levels and/or gene haplotype of thymidylate synthetase (TYMS) (Popat et al, 2004; Suh et al, 2005; Tsourouflis et al, 2008), microsatellite instability (MSI) (Gryfe et al, 2000; Popat et al, 2005), and chromosomal instability (CIN) (Walther et al, 2008). Nevertheless, none of these biomarkers has been prospectively validated and established so far in clinical practice. Hence, the identification of new, reliable prognostic and predictive biomarkers that will contribute utmost to clinical decision-making, remains an important research topic (Locker et al, 2006; Walther et al, 2009).

L-DOPA decarboxylase (DDC) is a pyridoxal 5-phosphate (PLP)-dependent enzyme that catalyses the decarboxylation of 3,4-dihydroxy-L-phenylalanine (L-DOPA) to dopamine (DA) and 5-hydroxy-L-tryptophan (S-HTP) to serotonin (5-HT) (Christenson et al, 1972). DDC is expressed in the central nervous system as well as in peripheral organs, such as the liver, kidney, pancreas and placenta (Lindstrom and Sehlin, 1983; Maneckjee and Baylin, 1983; Ichinose et al, 1989; Mappouras et al, 1990; Siaterli et al, 2003). Moreover, enzymatically active DDC was recently found in human leukocytes as well as in the histiocytic lymphoma cell line U-937, thus suggesting a cross-talk between the nervous and the immune systems and raising new questions about the regulatory role of DDC in immune responses (Kokkinou et al, 2009a, b). Recently, two endogenous inhibitors of the enzymatic activity of DDC have 
been identified and purified, one from human serum and another from the membrane fraction of human placental tissue, yet their biological significance remains unexplored (Vassiliou et al, 2005, 2009).

The structure of the human $D D C$ gene has been fully determined. The single-copy gene encoding $D D C$ maps to chromosome $7 \mathrm{p} 12.2$, close to the epidermal growth factor receptor (EGFR) gene, and is composed of 15 exons spanning a genomic region of more than $85 \mathrm{~kb}$ (Ichinose et al, 1989; Sumi-Ichinose et al, 1992). Furthermore, two other $D D C$ mRNA transcripts encoding distinct DDC protein isoforms as well as alternative splicing in $5^{\prime}$-untranslated region have been identified and characterised (Krieger et al, 1991; Ichinose et al, 1992; O’Malley et al, 1995; Vassilacopoulou et al, 2004).

It is worth mentioning that DDC is regarded as a general biomarker for neuroendocrine tumours (Gazdar et al, 1988; Gilbert et al, 1995; Ippolito et al, 2005). High DDC mRNA expression has been noticed in small-cell lung carcinoma (SCLC), neuroblastoma, and pheochromocytoma (Jensen et al, 1990; Gilbert et al, 1999; Uccella et al, 2006). Moreover, it has been suggested that $D D C$ mRNA levels could be a potential biomarker for the detection of minimal residual disease in patients with neuroblastoma and for the discrimination of neuroblastoma from other small round-cell tumours of childhood (Gilbert et al, 1999; Bozzi et al, 2004).

Recent studies revealed that DDC is also implicated in prostate cancer neuroendocrine differentiation, accounting for abnormal prostate cell proliferation and differentiation (Wafa et al, 2007), as it is an androgen receptor (AR) coregulator protein acting at the cytoplasmic level to enhance AR activity and to differentially modulate AR-regulated genes (Wafa et al, 2003; Margiotti et al, 2007). Not surprisingly, $D D C$ gene expression at the mRNA level has been proposed as a novel tissue biomarker in prostate cancer (Avgeris et al, 2008). DDC is also overexpressed in peritoneal dissemination of gastric carcinoma, and its quantification has been shown to be reliable and effective for the selection of patients for adjuvant intraperitoneal chemotherapy, aiming at preventing peritoneal recurrence (Sakakura et al, 2004). Still, the role of DDC in CRC remains unclear.

The above data encouraged us to analyse the $D D C$ mRNA expression in colorectal adenocarcinoma specimens, developing an ultra-sensitive and highly accurate quantitative real-time PCR methodology using the SYBR Green chemistry, and to examine its potential prognostic significance and clinical application as a novel molecular tissue biomarker for colorectal adenocarcinoma.

\section{MATERIALS AND METHODS}

\section{Tissue samples and RNA isolation}

Included in this study were tumour specimens from 95 patients having undergone surgical treatment for primary colorectal adenocarcinoma between 2000 and 2003. The selection criteria for the specimens included the availability of sufficient tissue mass for RNA extraction and assay. Tumour tissues had been frozen in liquid nitrogen immediately after their surgical resection.

Tissue specimens were pulverised and then dissolved in TRI Reagent (Ambion (Europe) Ltd., Huntingdon, UK). Following the manufacturer's instructions, we extracted and diluted total RNA in an RNA Storage Solution (Ambion Ltd), and stored it at $-80^{\circ} \mathrm{C}$ until use.

Patient age ranged from 35 to 88 years with a mean \pm s.e. of $67.3 \pm 1.01$. Other patients' characteristics and stage of tumours are shown in Tables 1-3. Follow-up information was available for 72 patients and included survival status (alive or deceased) and disease status (disease-free or recurrence/metastasis) along with the dates of the events and cause of death.

The study was performed with respect to the ethical standards of the 1975 Declaration of Helsinki Principles, as revised in 1996, and
Table I Distribution of numerical variables of the study in 95 colorectal adenocarcinoma patients

\begin{tabular}{lcccccc}
\hline & & & \multicolumn{3}{c}{ Percentiles } \\
\cline { 4 - 6 } & & & $\mathbf{2 5}$ & $\mathbf{5 0}$ & $\mathbf{7 5}$ \\
\cline { 4 - 7 } Variable & Mean \pm s.e. $^{\mathbf{a}}$ & Range & & \multicolumn{3}{c}{ Median } \\
\hline DDC in tumours (c/Kc $\left.{ }^{b}\right)$ & $9.02 \pm 1.51$ & $0.04-91.95$ & 0.17 & 3.09 & 12.82 \\
Patient age (years) & $67.3 \pm 1.01$ & $35-88$ & 62.0 & 68.0 & 75.0 \\
DFS (months) & $36.6 \pm 2.63$ & $0.5-79.0$ & 16.7 & 39.5 & 52.2 \\
OS (months) & $38.1 \pm 2.63$ & $0.5-79.0$ & 17.7 & 42.5 & 54.2 \\
\hline
\end{tabular}

Abbreviations: $\quad \mathrm{DDC}=\mathrm{L-DOPA}$ decarboxylase; $\mathrm{DFS}=$ disease-free survival; OS $=$ overall survival. ${ }^{a}$ Standard error of the mean. ${ }^{b} D D C$ mRNA copies per 1000 GAPDH mRNA copies.

Table 2 Relationships between DDC status ${ }^{\mathrm{a}}$ and other clinicopathological variables

\begin{tabular}{|c|c|c|c|c|}
\hline \multirow[b]{2}{*}{ Variable } & \multirow[b]{2}{*}{ Total } & \multicolumn{3}{|c|}{ Number of patients (\%) } \\
\hline & & $D D C$ negative ${ }^{a}$ & $D D C$ positive $\mathrm{a}^{\mathrm{a}}$ & $P$-value \\
\hline \multicolumn{5}{|l|}{ Nodal status } \\
\hline Positive & 49 & $35(71.4)$ & $14(28.6)$ & $0.63^{b}$ \\
\hline Negative & 41 & $32(78.0)$ & $9(22.0)$ & \\
\hline$x$ & 5 & & & \\
\hline \multicolumn{5}{|l|}{ Stage $e^{c}$} \\
\hline A/B & 47 & $33(70.2)$ & $14(29.8)$ & $0.13^{b}$ \\
\hline$C / D$ & 41 & $35(85.4)$ & $6(14.6)$ & \\
\hline$x$ & 7 & & & \\
\hline \multicolumn{5}{|c|}{ Histologic grade } \\
\hline 100 & 6 & $2(33.3)$ & $4(66.7)$ & $0.011^{d}$ \\
\hline$\|$ & 70 & 5 I (72.9) & $19(27.1)$ & \\
\hline III & 11 & $11(100)$ & $0(0.00)$ & \\
\hline$x$ & 8 & & & \\
\hline
\end{tabular}

Abbreviations: $\mathrm{DDC}=\mathrm{L-DOPA}$ decarboxylase; $\mathrm{x}=$ status unknown. ${ }^{\mathrm{a} C u t-o f f}$ point: $12.82 \mathrm{c} / \mathrm{Kc}$, equal to the 75 th percentile. ' $\mathrm{C}$ alculated by Fisher's exact test. 'Dukes' staging system. ${ }^{\mathrm{d}}$ Calculated by $\chi^{2}$-test.

Table 3 DDC expression and survival of patients with colorectal adenocarcinoma

\begin{tabular}{|c|c|c|c|c|c|c|}
\hline \multirow[b]{2}{*}{ Variable } & \multicolumn{3}{|c|}{ Disease-free survival } & \multicolumn{3}{|c|}{ Overall survival } \\
\hline & $H^{a}{ }^{a}$ & $95 \% \mathrm{Cl}^{\mathrm{b}}$ & $P$-value & $\mathbf{H R}^{\mathbf{a}}$ & $95 \% \mathrm{Cl}^{\mathrm{b}}$ & $P$-value \\
\hline \multicolumn{7}{|l|}{ Univariate analysis } \\
\hline \multicolumn{7}{|l|}{ DDC } \\
\hline Negative & 1.00 & & & 1.00 & & \\
\hline Positive & 0.18 & $0.043-0.77$ & 0.021 & 0.23 & $0.053-0.97$ & 0.047 \\
\hline As continuous variable & 0.96 & $0.93-1.00$ & 0.089 & 0.95 & $0.90-1.00$ & 0.089 \\
\hline Nodes positive & 1.80 & $0.83-3.89$ & 0.13 & 2.69 & $|| 1-6.5 \mid$. & 0.027 \\
\hline Stage (ordinal) & 2.31 & $1.42-3.73$ & 0.001 & 2.53 & $1.48-4.34$ & 0.001 \\
\hline Histologic grade (ordinal) & 3.07 & $1.33-7.05$ & 0.008 & 3.92 & $1.57-9.74$ & 0.003 \\
\hline \multicolumn{7}{|l|}{ Multivariate analysis ${ }^{c}$} \\
\hline \multicolumn{7}{|l|}{$D D C$} \\
\hline Negative & 1.00 & & & 1.00 & & \\
\hline Positive & 0.37 & $0.08-1.67$ & 0.19 & 0.56 & $0.12-2.67$ & 0.46 \\
\hline Nodes positive & 0.76 & $0.29-2.00$ & 0.58 & 1.14 & $0.36-3.58$ & 0.82 \\
\hline Stage (ordinal) & 2.31 & $1.30-4.10$ & 0.004 & 2.32 & $1.14-4.74$ & 0.021 \\
\hline Histologic grade (ordinal) & 2.13 & $0.86-5.30$ & 0.103 & 2.70 & $0.98-7.41$ & 0.054 \\
\hline
\end{tabular}

Abbreviations: $\mathrm{Cl}=$ confidence interval: $\mathrm{DDC}=\mathrm{L}-\mathrm{DOPA}$ decarboxylase; $\mathrm{HR}=$ hazard ratio. ${ }^{\text {aHR }}$ estimated from Cox proportional hazard regression model. ${ }^{\mathrm{b}} \mathrm{Cl}$ of the estimated HR. 'Multivariate models were adjusted for patients' nodal status, Dukes' stage, and histologic tumour grade. 
has been approved by the ethics committee of the University General Hospital ‘Attikon'.

\section{cDNA synthesis}

First-strand cDNA was produced from total RNA by using an RNA PCR Kit Version 3.0 (TaKaRa Bio Inc., Tokyo, Japan), according to the manufacturer's instructions. The reaction mixture contained $2 \mu \mathrm{g}$ of total RNA diluted in $11 \mu \mathrm{l}$ of diethylpyrocarbonate (DEPC)treated water, 2.5 pmol Oligo dT-Adaptor primer, $2 \mu \mathrm{l}$ RT Buffer $(10 \times, 100 \mathrm{~mm}$ Tris- $\mathrm{HCl}(\mathrm{pH}=8.3), 500 \mathrm{~mm} \mathrm{KCl}), 4 \mu \mathrm{l} 5 \mathrm{~mm} \mathrm{MgCl}_{2}$, $2 \mu \mathrm{l} 10 \mathrm{~mm}$ dNTP mix, $20 \mathrm{U}$ RNase inhibitor (Rnase Inhibitor; $40 \mathrm{U}^{-1}$; TaKaRa Bio Inc.) and 1.25 $\mathrm{U}$ reverse transcriptase (AMV Reverse Transcriptase XL; $5 \mathrm{U}^{-1} \mathrm{l}^{-1}$; TaKaRa Bio Inc.). The final reaction volume was $20 \mu \mathrm{l}$. The reaction mixture was incubated at $30^{\circ} \mathrm{C}$ for $10 \mathrm{~min}, 60^{\circ} \mathrm{C}$ for $30 \mathrm{~min}$, and the reaction was terminated by heating the mixture at $99^{\circ} \mathrm{C}$ for $5 \mathrm{~min}$ and cooling it at $5^{\circ} \mathrm{C}$ for $5 \mathrm{~min}$.

\section{Real-time quantitative PCR}

Quantitative real-time PCR was performed using the SYBR Green chemistry in a 7500 Real-Time PCR System (Applied Biosystems, Foster City, CA, USA) (Figure 1A). On the basis of the information of the DDC and GAPDH cDNA sequences, two pairs of genespecific primers were designed. The reaction mixture contained $50 \mathrm{ng}$ of cDNA diluted in $2.5 \mu \mathrm{l}$ of DEPC-treated water, $5 \mu \mathrm{l}$ Power SYBR Green PCR Master Mix $(2 \times)$ (Applied Biosystems), and $2 \mu \mathrm{l}$ of gene-specific primers (final concentration, $50 \mathrm{~nm}$ each), in a final reaction volume of $10 \mu \mathrm{l}$. The $D D C$ real-time PCR primers were $5^{\prime}$-GAACAGACTTAACGGGAGCCTTT- $3^{\prime}$ and $5^{\prime}$-AATGCCGG TAGTCAGTGATAAGC-3', producing a 90-bp PCR amplicon, and the GAPDH real-time PCR primers were $5^{\prime}$-ATGGGGAAGGTG AAGGTCG- $3^{\prime}$ and $5^{\prime}$-GGGTCATTGATGGCAACAATATC- ${ }^{\prime}$, resulting in a 107-bp PCR amplicon. The cycling conditions were as follow: a denaturation step at $95^{\circ} \mathrm{C}$ for $10 \mathrm{~min}$, followed by 40 cycles of $95^{\circ} \mathrm{C}$ for $15 \mathrm{~s}, 60^{\circ} \mathrm{C}$ for $60 \mathrm{~s}$, and a final step for the generation of a dissociation curve to distinguish between the main PCR product and primer-dimers (Figure 1B).

Calculations were made with the use of the comparative $C_{T}$ $\left(2^{-\Delta \Delta \mathrm{C}_{\mathrm{T}}}\right)$ method. GAPDH was used as an internal control gene to normalise the PCRs for the amount of RNA added to the reverse transcription reactions, whereas the breast adenocarcinoma epithelial cell line MCF7 was used as a calibrator for making PCRs from distinct runs comparable (Livak and Schmittgen, 2001). $\Delta \Delta \mathrm{C}_{\mathrm{T}}$ represents the difference between the mean $\Delta \mathrm{C}_{\mathrm{T}}$ value of a colon sample and the mean $\Delta \mathrm{C}_{\mathrm{T}}$ of the calibrator, both calculated after the same PCR run, whereas $\Delta C_{T}$ is the difference between the threshold cycle $\left(C_{\mathrm{T}}\right)$ of the target gene $(D D C)$ and the $\mathrm{C}_{\mathrm{T}}$ of the endogenous reference gene $(G A P D H)$ of the same sample.

Normalised results were expressed as the ratio of $D D C$ mRNA copies to GAPDH mRNA copies calculated for each colon tissue sample in relation to the same ratio calculated for MCF7 cells. The normalised $\left(2^{-\Delta \Delta \mathrm{C}_{\mathrm{T}}}\right)$ amounts of tissue sample $D D C$ mRNA levels were then multiplied with the average ratio of $D D C$ mRNA copies to GAPDH mRNA copies of MCF7 cells $\left(2^{-13.384}\right)$, calculated from the intercept of the regression line shown in Figure 1C, thus resulting in comparable results that do not depend on the $D D C$ mRNA expression levels of MCF7 cells. Finally, these results were multiplied by 1000 , thus yielding $\mathrm{c} / \mathrm{Kc}$ ( $D D C$ mRNA copies per 1000 GAPDH mRNA copies). Each real-time PCR reaction was performed in triplicate to evaluate the reproducibility of data.

\section{Statistical analysis}

The X-tile algorithm was used to generate an optimal cut-off point for DDC (Camp et al, 2004), as there are no established cut-off points concerning its expression in colorectal adenocarcinoma.

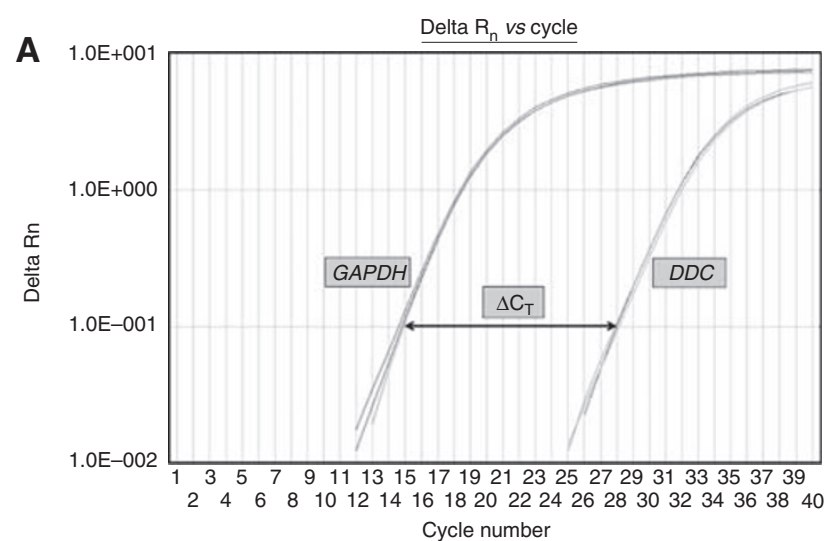

B
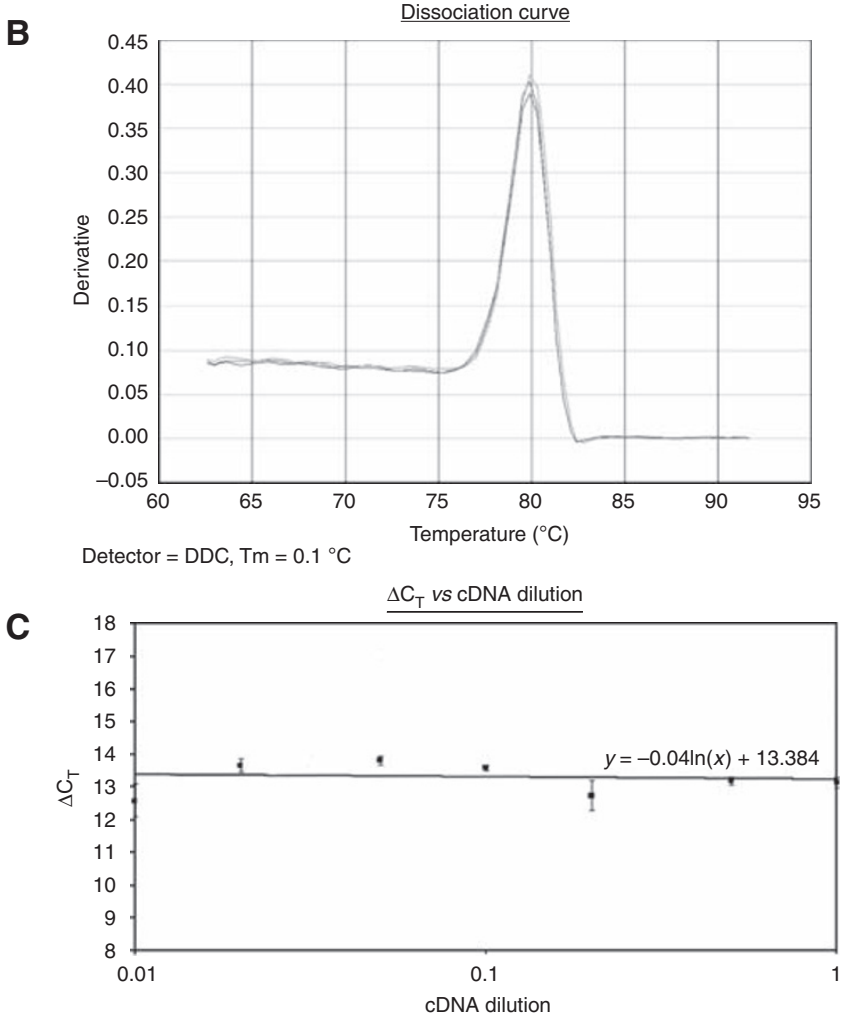

Figure I Real-time PCR quantification of DDC gene expression in colon tissues. (A) Amplification plot of DDC and GAPDH CDNAs, showing $\Delta R_{n}$ plotted vs cycle number. DDC mRNA expression was detected by real-time quantitative PCR, using the SYBR Green chemistry, while GAPDH served as a reference gene. Calculations were made with the use of the comparative $C_{T}\left(2^{-\Delta \Delta C_{\mathrm{T}}}\right)$ method. (B) Dissociation curves of the DDC amplicon, showing the specificity of primers used for the real-time PCR amplification and quantification of DDC. Neither primer-dimers nor other non-specific products were observed after melting of the PCR products. (C) Validation of the comparative $C_{T}\left(2^{-\Delta \Delta C_{\mathrm{T}}}\right)$ method. The efficiency of the amplification of the target gene (DDC) and internal control (GAPDH) was examined by means of real-time PCR and SYBR Green detection. With the use of reverse transcriptase, cDNA was synthesised from $2 \mu \mathrm{g}$ total RNA isolated from human MCF7 cells. Serial dilutions of cDNA over a I00-fold range were amplified by real-time PCR using gene-specific primers. The most concentrated sample contained cDNA derived from $100 \mathrm{ng}$ of total RNA. The $\Delta C_{T}\left(C_{T, D D C}-C_{T, G A P D H}\right)$ was calculated for each cDNA dilution and plotted vs it. All data were fit using least-square linear regression analysis. The absolute value of the slope of the resulting plot is almost equal to zero, which indicates that the amplification efficiencies for both genes are similar. 
Having corrected for the use of minimum $P$-value statistics, the $\mathrm{X}$-tile software yielded an optimal cut-off of $12.82 \mathrm{c} / \mathrm{Kc}$, equal to the 75th percentile, with a calculated Monte Carlo $P$-value $<0.05$. According to this cut-off, $D D C$ mRNA expression was classified as positive or negative, and associations between $D D C$ status and other qualitative clinicopathological parameters were analysed using the $\chi^{2}$-test or the Fisher's exact test, where appropriate.

Cox proportional hazard regression model was developed to assess the association between the prognostic markers and the relative risks for relapse and death of patients (Cox, 1972). Cox analysis was conducted at both univariate and multivariate levels. Only patients for whom the status of all variables was known were included in the multivariate regression models, which incorporated $D D C$ mRNA expression and all other variables for which the patients were characterised. The multivariate models were adjusted for nodal status, histologic tumour grade, and Dukes' stage (Dukes, 1932; Hamilton and Aaltonen, 2000).

Survival analyses were also performed by constructing KaplanMeier disease-free survival (DFS) and overall survival (OS) curves (Kaplan and Meier, 1958). The differences between the curves were evaluated by the log-rank test.

\section{RESULTS}

\section{Validation of the comparative $\mathrm{C}_{\mathrm{T}}\left(2^{-\Delta \Delta \mathrm{C}_{\mathrm{T}}}\right)$ method for $D D C$} mRNA quantification

For the $\Delta \Delta \mathrm{C}_{\mathrm{T}}$ calculation to be valid, the amplification efficiencies of the target and reference genes must be approximately equal (Livak and Schmittgen, 2001). For this purpose, the $C_{\mathrm{T}}$ values for $D D C$ and GAPDH, corresponding to the number of cycles at which the fluorescence emission monitored in real time reached a threshold of 10 times the standard deviation of the mean baseline emission from cycles 3 to 15 (Figure 1A) (Giulietti et al, 2001), were measured in serial dilutions of a control cDNA over a 100fold range, and the $\Delta \mathrm{C}_{\mathrm{T}}$ (namely the difference $\mathrm{C}_{\mathrm{T}, D D C}-\mathrm{C}_{\mathrm{T}, G A P D H}$ ) was plotted $v s$ the log cDNA dilution. The absolute value of the slope of the resulting plot is close to zero, which implies similar amplification efficiencies of both amplicons (Figure 1C).

\section{$D D C$ expression status in colorectal adenocarcinoma tissues and its association with patients' clinicopathological variables}

mRNA expression of $D D C$ in colorectal adenocarcinoma tissues varied from 0.04 to $91.95 \mathrm{c} / \mathrm{Kc}$ ( $D D C$ mRNA copies per 1000 GAPDH mRNA copies) with a mean \pm s.e. of $9.02 \pm 1.51$ (Table 1).
Table 2 shows the association of $D D C$ mRNA expression status of the tumour with various clinicopathological variables. $D D C$ values were classified into two categories (positive or negative), as described in the Materials and Methods section. Out of 95 colon adenocarcinomas examined, $24(25.3 \%)$ were classified as positive for $D D C$ expression and $71(74.7 \%)$ as negative. $D D C$ positivity was found more frequently in well-differentiated tumours, whereas high-grade colorectal tumours were found to be $D D C$-negative $(P=0.011)$. Significant associations between $D D C$ status and patient age, nodal status, or Dukes' stage were not observed.

\section{$D D C$ expression status and colorectal adenocarcinoma survival}

Complete follow-up information was available for 72 patients, among whom 27 (38\%) had relapsed and 22 (31\%) had died. In Cox univariate analysis, histologic tumour grade, and disease Dukes' stage were significant predictors of DFS and OS, as expected. In addition to these established prognostic factors, $D D C$ mRNA expression was found to be an important predictor of DFS and OS $(P=0.021$ and $P=0.047$, respectively). $D D C$-positive patients were found to have a significant lower risk to relapse $(\mathrm{HR}=0.18)$ or die $(\mathrm{HR}=0.23)$ (Table 3$)$. The Kaplan-Meier survival curves also show that patients with $D D C$-positive tumours have remarkably longer DFS $(P=0.009)$ and OS $(P=0.027)$, compared to those with $D D C$-negative malignancies (Figure 2$)$. In multivariate analysis, when all parameters were included in the Cox regression model, only Dukes' stage retained its prognostic significance for DFS and OS of patients with colorectal adenocarcinoma $(P=0.004$ and $P=0.021$, respectively) (Table 3$)$.

\section{DISCUSSION}

Cancer of the colon and rectum is an important public health issue, constituting a major cause of worldwide morbidity and mortality (Pisani et al, 2002; Jemal et al, 2009). In Europe, CRC is the second most common malignancy among women after breast cancer and the third most frequent in men after prostate and lung cancer. Moreover, CRC is the second most common cause of cancer death for both sexes, accounting for $12 \%$ of all tumour-related deaths (Parkin et al, 2001b; Ferlay et al, 2010). Early diagnosis of CRC and early detection of recurrence after surgery are critical for effective treatment and/or positive clinical outcome. Endoscopic examination of the colon remains the most reliable screening method for this type of malignancy (Newcomb et al, 1992; Lieberman et al, 2000).
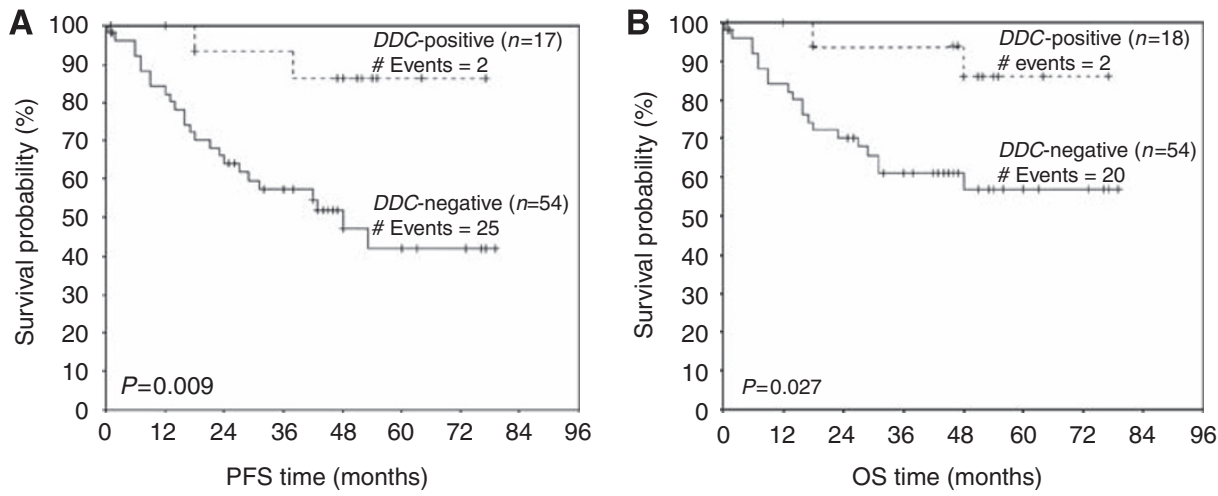

Figure 2 Kaplan-Meier survival curves. Kaplan-Meier curves for disease-free survival (DFS) (A) and overall survival (OS) (B) of patients with DDC-positive and DDC-negative colorectal adenocarcinoma. DDC expression was found to have a favourable prognostic value for colorectal adenocarcinoma, as patients with DDC-positive colorectal adenocarcinoma have significantly longer DFS $(P=0.009)$ and OS $(P=0.027)$, in comparison with those whose tumours are DDC-negative. 
All existing classification systems for CRC distinguish between patients with early-stage CRC and those with very advanced-stage disease; nonetheless, they are less efficient in predicting the prognosis of patients with intermediate levels of tumour burden (McLeod and Murray, 1999). On the basis of studies published over the last few years, the American Society of Clinical Oncology Tumour Marker Panel and the European Group on Tumour Markers have recently suggested that preoperative carcinoembryonic antigen (CEA) levels may be used as an independent prognostic factor, assisting in staging and surgical treatment planning. It should also be noted that CEA is the marker of choice for monitoring the response of metastatic disease to systemic therapy (Duffy et al, 2003; Locker et al, 2006). However, neither CEA nor any other biomarkers that have been proposed in the past, such as CA19-9, have enough sensitivity for colon cancer detection (van der Schouw et al, 1992; Pokorny et al, 2000; Locker et al, 2006).

L-DOPA decarboxylase is a PLP-dependent enzyme participating in the catecholamine biosynthesis pathway, responsible principally for the synthesis of the key neurotransmitters DA and 5-HT (Christenson et al, 1972). Biogenic amines are generally considered to participate in various processes, such as angiogenesis, cell proliferation, differentiation and apoptosis (Berry et al, 1996; Medina et al, 1999; Lang et al, 2005), which implies a potentially significant role of DDC in cancer pathobiology and progression. Interestingly enough, it has recently been shown that catecholamines, including DA itself, inhibit erythrocyte apoptosis by preventing scramblase activation and subsequent phosphatidylserine exposure on the cell membrane (Lang et al, 2005), which in turn triggers clearance of apoptotic cells by macrophages.

$D D C$ mRNA expression is used for the differential diagnosis of neuroblastoma from other pediatric small round-cell malignancies (Gilbert et al, 1999; Bozzi et al, 2004). Quantification of DDC mRNA expression using real-time RT-PCR has been proposed as a method useful for the prediction of peritoneal recurrence in patients with gastric carcinoma (Sakakura et al, 2004). In addition, DDC protein expression is a biomarker of neuroendocrine differentiation in SCLC cells and prostate carcinoma (Gilbert et al, 2000; Wafa et al, 2007). DDC mRNA levels were also found to be particularly elevated in cancerous prostate tissue, in comparison with benign prostate hyperplasia. High-expression levels of $D D C$ were found to be associated with more aggressive prostate tumours (Avgeris et al, 2008).

Several peripheral cancers are characterised by an extremely high DDC activity, associated with the tumour. This is especially apparent with lung cancers of small-cell origin, although variants showing no protein expression have been observed as well (Berry et al, 1996). Remarkable increase in DDC activity, in comparison with normal tissue levels, is also seen in primary intestinal cancer and its related metastases in the spleen and liver (Gilbert et al, 1995). The significance of this increase in DDC activity and resultant monoamine synthesis by the cancer cells is still unknown (Berry et al, 1996), yet it is closely related to the implication of DDC in cancer.

In this study, we investigated the expression of the $D D C$ gene in colorectal adenocarcinoma and its prognostic significance. Our study revealed a statistically significant, negative association between $D D C$ mRNA expression levels and the histologic tumour grade $(P=0.011)$. Colorectal tumours of low histologic grade (I) were more frequently $D D C$-positive, in contrast with malignancies of high grade (II/III). These data seem to indicate that higher $D D C$ expression is associated with well-differentiated intestinal tumours.

In accordance with the above-mentioned results, the KaplanMeier analysis showed significantly higher DFS and OS time for patients having positive $D D C$ mRNA expression $(P=0.009$ and $P=0.027$, respectively). Cox univariate regression analysis showed that $D D C$-positive patients had a significantly lower risk of relapse ( $\sim 5$ times) and a higher probability of survival ( $\sim 4$ times). In the Cox multivariate regression model, the levels of $D D C$ mRNA were adjusted for patients' nodal status, Dukes' stage and histologic tumour grade. When all these non-molecular parameters were included in the multivariate analysis model, $D D C$ mRNA expression did not show statistically significant independence as a prognostic factor for DFS or OS of patients with colorectal adenocarcinoma.

In conclusion, this study revealed that higher mRNA expression levels of $D D C$ are related with less advanced and/or aggressive tumours. Our results imply that $D D C$ mRNA overexpression is linked to favorable prognosis in patients with colorectal adenocarcinoma and may constitute a useful tissue biomarker. Involvement of DDC in apoptosis of colon cancer cells and/or response of $D D C$-positive tumours to chemotherapy are two potential explanations, but further investigation is required to clarify the role of DDC in CRC.

\section{ACKNOWLEDGEMENTS}

The project was supported by a PENED grant co-funded by the European Union - European Social Funds (75\%) and National Resources - Ministry of Development - General Secretariat for Research \& Technology of Greece (25\%) as well as ELPEN A.E. through EPAN.M.8.3 - 3rd Community Support Programme.

\section{REFERENCES}

Alazzouzi H, Alhopuro P, Salovaara R, Sammalkorpi H, Jarvinen $H$, Mecklin JP, Hemminki A, Schwartz Jr S, Aaltonen LA, Arango D (2005) SMAD4 as a prognostic marker in colorectal cancer. Clin Cancer Res 11: 2606-2611

Avgeris M, Koutalellis G, Fragoulis EG, Scorilas A (2008) Expression analysis and clinical utility of L-Dopa decarboxylase (DDC) in prostate cancer. Clin Biochem 41: $1140-1149$

Berry MD, Juorio AV, Li XM, Boulton AA (1996) Aromatic L-amino acid decarboxylase: a neglected and misunderstood enzyme. Neurochem Res 21: $1075-1087$

Boulay JL, Mild G, Lowy A, Reuter J, Lagrange M, Terracciano L, Laffer U, Herrmann R, Rochlitz C (2002) SMAD4 is a predictive marker for 5-fluorouracil-based chemotherapy in patients with colorectal cancer. Br J Cancer 87: 630-634

Bozzi F, Luksch R, Collini P, Gambirasio F, Barzano E, Polastri D, Podda M, Brando B, Fossati-Bellani F (2004) Molecular detection of dopamine decarboxylase expression by means of reverse transcriptase and polymerase chain reaction in bone marrow and peripheral blood: utility as a tumor marker for neuroblastoma. Diagn Mol Pathol 13: $135-143$

Camp RL, Dolled-Filhart M, Rimm DL (2004) X-tile: a new bio-informatics tool for biomarker assessment and outcome-based cut-point optimization. Clin Cancer Res 10: $7252-7259$

Christenson JG, Dairman W, Udenfriend S (1972) On the identity of DOPA decarboxylase and 5-hydroxytryptophan decarboxylase (immunological titration-aromatic L-amino acid decarboxylase-serotonin-dopaminenorepinephrine). Proc Natl Acad Sci USA 69: 343-347

Compton CC, Greene FL (2004) The staging of colorectal cancer: 2004 and beyond. CA Cancer J Clin 54: 295-308

Cox DR (1972) Regression models and life tables. R Stat Soc B 34: 187-202

Duffy MJ, van Dalen A, Haglund C, Hansson L, Klapdor R, Lamerz R, Nilsson O, Sturgeon C, Topolcan O (2003) Clinical utility of biochemical 
markers in colorectal cancer: European Group on Tumour Markers (EGTM) guidelines. Eur J Cancer 39: 718-727

Dukes CE (1932) The classification of cancer of the rectum. J Pathol Bacteriol 35: 323

Ferlay J, Parkin DM, Steliarova-Foucher E (2010) Estimates of cancer incidence and mortality in Europe in 2008. Eur J Cancer 46: 765-781

Gazdar AF, Helman LJ, Israel MA, Russell EK, Linnoila RI, Mulshine JL, Schuller HM, Park JG (1988) Expression of neuroendocrine cell markers L-Dopa decarboxylase, chromogranin A, and dense core granules in human tumors of endocrine and nonendocrine origin. Cancer Res 48: $4078-4082$

Gilbert J, Haber M, Bordow SB, Marshall GM, Norris MD (1999) Use of tumor-specific gene expression for the differential diagnosis of neuroblastoma from other pediatric small round-cell malignancies. Am J Pathol 155: 17-21

Gilbert JA, Bates LA, Ames MM (1995) Elevated aromatic-L-amino acid decarboxylase in human carcinoid tumors. Biochem Pharmacol 50: $845-850$

Gilbert JA, Frederick LM, Ames MM (2000) The aromatic-L-amino acid decarboxylase inhibitor carbidopa is selectively cytotoxic to human pulmonary carcinoid and small cell lung carcinoma cells. Clin Cancer Res 6: $4365-4372$

Giulietti A, Overbergh L, Valckx D, Decallonne B, Bouillon R, Mathieu C (2001) An overview of real-time quantitative PCR: applications to quantify cytokine gene expression. Methods 25: 386-401

Gryfe R, Kim H, Hsieh ET, Aronson MD, Holowaty EJ, Bull SB, Redston M, Gallinger S (2000) Tumor microsatellite instability and clinical outcome in young patients with colorectal cancer. $N$ Engl J Med 342: $69-77$

Hamilton SR, Aaltonen LA (eds) (2000) Pathology and Genetics. In Tumours of the Digestive System. IARC Press: Lyon

Ichinose H, Kurosawa Y, Titani K, Fujita K, Nagatsu T (1989) Isolation and characterization of a cDNA clone encoding human aromatic L-amino acid decarboxylase. Biochem Biophys Res Commun 164: $1024-1030$

Ichinose H, Sumi-Ichinose C, Ohye T, Hagino Y, Fujita K, Nagatsu T (1992) Tissue-specific alternative splicing of the first exon generates two types of mRNAs in human aromatic L-amino acid decarboxylase. Biochemistry 31: $11546-11550$

Ippolito JE, Xu J, Jain S, Moulder K, Mennerick S, Crowley JR, Townsend RR, Gordon JI (2005) An integrated functional genomics and metabolomics approach for defining poor prognosis in human neuroendocrine cancers. Proc Natl Acad Sci USA 102: 9901 - 9906

Jemal A, Siegel R, Ward E, Hao Y, Xu J, Thun MJ (2009) Cancer statistics, 2009. CA Cancer J Clin 59: 225-249

Jen J, Kim H, Piantadosi S, Liu ZF, Levitt RC, Sistonen P, Kinzler KW, Vogelstein B, Hamilton SR (1994) Allelic loss of chromosome 18q and prognosis in colorectal cancer. $N$ Engl J Med 331: 213-221

Jensen SM, Gazdar AF, Cuttitta F, Russell EK, Linnoila RI (1990) A comparison of synaptophysin, chromogranin, and L-Dopa decarboxylase as markers for neuroendocrine differentiation in lung cancer cell lines. Cancer Res 50: 6068-6074

Kaplan EL, Meier P (1958) Nonparametric observation from incomplete observations. J Am Stat Assoc 53: 457-481

Kokkinou I, Fragoulis EG, Vassilacopoulou D (2009a) The U937 macrophage cell line expresses enzymatically active L-Dopa decarboxylase. J Neuroimmunol 216: $51-58$

Kokkinou I, Nikolouzou E, Hatzimanolis A, Fragoulis EG, Vassilacopoulou D (2009b) Expression of enzymatically active L-DOPA decarboxylase in human peripheral leukocytes. Blood Cells $\mathrm{Mol}$ Dis 42: $92-98$

Krieger M, Coge F, Gros F, Thibault J (1991) Different mRNAs code for Dopa decarboxylase in tissues of neuronal and nonneuronal origin. Proc Natl Acad Sci USA 88: 2161-2165

Lang PA, Kempe DS, Akel A, Klarl BA, Eisele K, Podolski M, Hermle T, Niemoeller OM, Attanasio P, Huber SM, Wieder T, Lang F, Duranton C (2005) Inhibition of erythrocyte 'apoptosis' by catecholamines. Naunyn Schmiedebergs Arch Pharmacol 372: 228-235

Lieberman DA, Weiss DG, Bond JH, Ahnen DJ, Garewal H, Chejfec G (2000) Use of colonoscopy to screen asymptomatic adults for colorectal cancer. Veterans Affairs Cooperative Study Group 380. N Engl J Med 343: $162-168$

Lindstrom P, Sehlin J (1983) Mechanisms underlying the effects of 5-hydroxytryptamine and 5-hydroxytryptophan in pancreatic islets. A proposed role for L-aromatic amino acid decarboxylase. Endocrinology 112: $1524-1529$
Livak KJ, Schmittgen TD (2001) Analysis of relative gene expression data using real-time quantitative PCR and the 2(-Delta Delta $\mathrm{C}(\mathrm{T})$ ) method. Methods 25: $402-408$

Locker GY, Hamilton S, Harris J, Jessup JM, Kemeny N, Macdonald JS, Somerfield MR, Hayes DF, Bast Jr RC (2006) ASCO 2006 update of recommendations for the use of tumor markers in gastrointestinal cancer. J Clin Oncol 24: 5313-5327

Maneckjee R, Baylin SB (1983) Use of radiolabeled monofluoromethylDopa to define the subunit structure of human L-Dopa decarboxylase. Biochemistry 22: 6058-6063

Mappouras DG, Stiakakis J, Fragoulis EG (1990) Purification and characterization of L-Dopa decarboxylase from human kidney. Mol Cell Biochem 94: 147-156

Margiotti K, Wafa LA, Cheng H, Novelli G, Nelson CC, Rennie PS (2007) Androgen-regulated genes differentially modulated by the androgen receptor coactivator L-Dopa decarboxylase in human prostate cancer cells. Mol Cancer 6: 38

Martinez-Lopez E, Abad A, Font A, Monzo M, Ojanguren I, Pifarre A, Sanchez JJ, Martin C, Rosell R (1998) Allelic loss on chromosome 18q as a prognostic marker in stage II colorectal cancer. Gastroenterology 114: $1180-1187$

McLeod HL, Murray GI (1999) Tumour markers of prognosis in colorectal cancer. Br J Cancer 79: 191-203

Medina MA, Quesada AR, Nunez de Castro I, Sanchez-Jimenez F (1999) Histamine, polyamines, and cancer. Biochem Pharmacol 57: 1341-1344

Munro AJ, Lain S, Lane DP (2005) P53 abnormalities and outcomes in colorectal cancer: a systematic review. Br J Cancer 92: 434-444

Newcomb PA, Norfleet RG, Storer BE, Surawicz TS, Marcus PM (1992) Screening sigmoidoscopy and colorectal cancer mortality. J Natl Cancer Inst 84: $1572-1575$

O'Malley KL, Harmon S, Moffat M, Uhland-Smith A, Wong S (1995) The human aromatic L-amino acid decarboxylase gene can be alternatively spliced to generate unique protein isoforms. J Neurochem 65: 2409-2416

Ogunbiyi OA, Goodfellow PJ, Herfarth K, Gagliardi G, Swanson PE, Birnbaum EH, Read TE, Fleshman JW, Kodner IJ, Moley JF (1998) Confirmation that chromosome $18 \mathrm{q}$ allelic loss in colon cancer is a prognostic indicator. J Clin Oncol 16: 427-433

Parkin DM, Bray F, Ferlay J, Pisani P (2001a) Estimating the world cancer burden: Globocan 2000. Int J Cancer 94: 153-156

Parkin DM, Bray FI, Devesa SS (2001b) Cancer burden in the year 2000. The global picture. Eur J Cancer 37(Suppl 8): S4-S66

Pisani P, Bray F, Parkin DM (2002) Estimates of the world-wide prevalence of cancer for 25 sites in the adult population. Int J Cancer 97: 72-81

Pokorny RM, Hunt L, Galandiuk S (2000) What's new with tumor markers for colorectal cancer? Dig Surg 17: 209-215

Popat S, Houlston RS (2005) A systematic review and meta-analysis of the relationship between chromosome $18 \mathrm{q}$ genotype, DCC status and colorectal cancer prognosis. Eur J Cancer 41: 2060-2070

Popat S, Hubner R, Houlston RS (2005) Systematic review of microsatellite instability and colorectal cancer prognosis. J Clin Oncol 23: 609-618

Popat S, Matakidou A, Houlston RS (2004) Thymidylate synthase expression and prognosis in colorectal cancer: a systematic review and meta-analysis. J Clin Oncol 22: 529-536

Reymond MA, Dworak O, Remke S, Hohenberger W, Kirchner T, Kockerling F (1998) DCC protein as a predictor of distant metastases after curative surgery for rectal cancer. Dis Colon Rectum 41: 755-760

Russo A, Bazan V, Iacopetta B, Kerr D, Soussi T, Gebbia N (2005) The TP53 colorectal cancer international collaborative study on the prognostic and predictive significance of p53 mutation: influence of tumor site, type of mutation, and adjuvant treatment. J Clin Oncol 23: 7518-7528

Sakakura C, Takemura M, Hagiwara A, Shimomura K, Miyagawa K, Nakashima S, Yoshikawa T, Takagi T, Kin S, Nakase Y, Fujiyama J, Hayasizaki Y, Okazaki Y, Yamagishi H (2004) Overexpression of Dopa decarboxylase in peritoneal dissemination of gastric cancer and its potential as a novel marker for the detection of peritoneal micrometastases with real-time RT-PCR. Br J Cancer 90: 665-671

Shibata D, Reale MA, Lavin P, Silverman M, Fearon ER, Steele Jr G, Jessup JM, Loda M, Summerhayes IC (1996) The DCC protein and prognosis in colorectal cancer. N Engl J Med 335: 1727-1732

Siaterli MZ, Vassilacopoulou D, Fragoulis EG (2003) Cloning and expression of human placental L-Dopa decarboxylase. Neurochem Res 28: $797-803$

Steinberg SM, Barkin JS, Kaplan RS, Stablein DM (1986) Prognostic indicators of colon tumors. The Gastrointestinal Tumor Study Group experience. Cancer 57: $1866-1870$ 
Suh KW, Kim JH, Kim YB, Kim J, Jeong S (2005) Thymidylate synthase gene polymorphism as a prognostic factor for colon cancer. J Gastrointest Surg 9: $336-342$

Sumi-Ichinose C, Ichinose H, Takahashi E, Hori T, Nagatsu T (1992) Molecular cloning of genomic DNA and chromosomal assignment of the gene for human aromatic L-amino acid decarboxylase, the enzyme for catecholamine and serotonin biosynthesis. Biochemistry 31: 2229-2238

Sun XF, Carstensen JM, Zhang H, Stal O, Wingren S, Hatschek T, Nordenskjold B (1992) Prognostic significance of cytoplasmic p53 oncoprotein in colorectal adenocarcinoma. Lancet 340: 1369-1373

Tsourouflis G, Theocharis SE, Sampani A, Giagini A, Kostakis A, Kouraklis G (2008) Prognostic and predictive value of thymidylate synthase expression in colon cancer. Dig Dis Sci 53: 1289-1296

Uccella S, Cerutti R, Vigetti D, Furlan D, Oldrini R, Carnevali I, Pelosi G, La Rosa S, Passi A, Capella C (2006) Histidine decarboxylase, DOPA decarboxylase, and vesicular monoamine transporter 2 expression in neuroendocrine tumors: immunohistochemical study and gene expression analysis. J Histochem Cytochem 54: 863-875

van der Schouw YT, Verbeek AL, Wobbes T, Segers MF, Thomas CM (1992) Comparison of four serum tumour markers in the diagnosis of colorectal carcinoma. Br J Cancer 66: $148-154$

Vassilacopoulou D, Sideris DC, Vassiliou AG, Fragoulis EG (2004) Identification and characterization of a novel form of the human L-Dopa decarboxylase mRNA. Neurochem Res 29: 1817-1823
Vassiliou AG, Fragoulis EG, Vassilacopoulou D (2009) Detection, purification and identification of an endogenous inhibitor of L-Dopa decarboxylase activity from human placenta. Neurochem Res 34: $1089-1100$

Vassiliou AG, Vassilacopoulou D, Fragoulis EG (2005) Purification of an endogenous inhibitor of L-Dopa decarboxylase activity from human serum. Neurochem Res 30: $641-649$

Wafa LA, Cheng H, Rao MA, Nelson CC, Cox M, Hirst M, Sadowski I, Rennie PS (2003) Isolation and identification of L-Dopa decarboxylase as a protein that binds to and enhances transcriptional activity of the androgen receptor using the repressed transactivator yeast two-hybrid system. Biochem J 375: $373-383$

Wafa LA, Palmer J, Fazli L, Hurtado-Coll A, Bell RH, Nelson CC, Gleave ME, Cox ME, Rennie PS (2007) Comprehensive expression analysis of L-Dopa decarboxylase and established neuroendocrine markers in neoadjuvant hormone-treated versus varying Gleason grade prostate tumors. Hum Pathol 38: $161-170$

Walther A, Houlston R, Tomlinson I (2008) Association between chromosomal instability and prognosis in colorectal cancer: a metaanalysis. Gut 57: $941-950$

Walther A, Johnstone E, Swanton C, Midgley R, Tomlinson I, Kerr D (2009) Genetic prognostic and predictive markers in colorectal cancer. Nat Rev Cancer 9: 489-499 